Article

\title{
Lecturer Competence from the Perspective of Undergraduate Psychology Students: A Qualitative Pilot Study
}

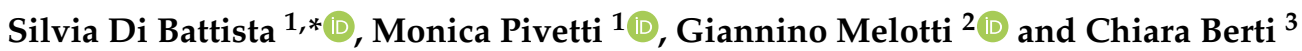 \\ 1 Department of Human and Social Sciences, University of Bergamo, Via Salvecchio 19, 24129 Bergamo, Italy; \\ monica.pivetti@unibg.it \\ 2 Department of Education Studies "Giovanni Maria Bertin", University of Bologna, Via Zamboni 33, \\ 40126 Bologna, Italy; giannino.melotti@unibo.it \\ 3 Department of Psychological, Health and Territorial Sciences, "G. d'Annunzio" University of Chieti-Pescara, \\ Via dei Vestini 31, 66100 Chieti, Italy; chiara.berti@unich.it \\ * Correspondence: silvia.dibattista@unibg.it
}

check for updates

Citation: Di Battista, S.; Pivetti, M.; Melotti, G.; Berti, C. Lecturer Competence from the Perspective of Undergraduate Psychology Students: A Qualitative Pilot Study. Educ. Sci. 2022, 12, 139. https://doi.org/ 10.3390/educsci12020139

Academic Editor: James Albright

Received: 15 January 2022

Accepted: 16 February 2022

Published: 19 February 2022

Publisher's Note: MDPI stays neutral with regard to jurisdictional claims in published maps and institutional affiliations.

Copyright: (C) 2022 by the authors. Licensee MDPI, Basel, Switzerland. This article is an open access article distributed under the terms and conditions of the Creative Commons Attribution (CC BY) license (https:// creativecommons.org/licenses/by/ $4.0 /)$

\begin{abstract}
Understanding what students mean by lecturer competence can be crucial in order to recognise indicators with which to assess these competences, improve the quality of university teaching and support lecturers in undertaking their role appropriately. This qualitative pilot study aimed to explore the meaning of competence in a convenience sample of Italian undergraduate psychology students $(N=122)$. We collected free-associations about what "lecturer competence" actually means for the students. The data corpus underwent a lexical Correspondence Analysis (CA) using the ASPAR procedure of SPAD-T. Two factors were extracted: "socio-emotional dimension" and "task specialist." Students associated the competent lecturer with those who was involved with the achievement of the task goals, on the one hand or those who was engaged in the group's maintenance, on the other. Furthermore, Cluster Analysis identified four clusters: (1) the captivating lecturer; (2) the lecturer oriented to both task and socio-emotional aspects; (3) the rigorous lecturer; and (4) the benevolent lecturer. The preliminary results of this pilot study showed an articulated and multi-dimensional representation of the meanings of lecturer competence from the students' point of view and lay the foundations for a broader quantitative study on the conceptions concerning lecturer competence.
\end{abstract}

Keywords: lecturer competence; pilot study; qualitative methods; higher education

\section{Introduction}

Professional competence is an important topic in the academic context, albeit relatively unexplored, and elaborated with contradictory conclusions as to its characteristics. Mulder and colleagues [1] described competence as consisting of a series of "clusters of knowledge, skills and attitudes necessarily conditional for task performance and problem-solving and for being able to function effectively in a certain profession, organisation, job, role and situation" (p. 757).

In education, according to some researchers [2], the term "competence" indicates the capacity to use knowledge, skills, personal, social and/or methodological abilities in response to specific situations and problems. A competent lecturer is not only the person who has a large amount of knowledge, but is also a person capable of dealing with a contingent situation and who knows how act effectively in a specific situation by making the best use of his/her resources [2]. Westera [3] argued that the term "competence" lacks a commonly accepted definition and he identified two main perspectives of competence in education. From a theoretical perspective, competence was described as a cognitive structure that facilitates specific behaviours. From an operational perspective, competence was seen as a series of skills and behaviours that represent the capacity to cope with complex and unpredictable situations. García-Valcárcel [4] asserted that "good lecturers" should 
mainly respond to their students' needs and demands. Therefore, there are problems of a theoretical nature concerning the lack of a single definition of the construct of lecturer competence [5]. A number of studies have explored a similar issue by making use of a plethora of concepts, such as "effective teaching" [6-8], "good teaching" [9-12], or "quality teaching" [13]. Even if a unitary definition and understanding of what competence represents is lacking, the development of reliable methods for the evaluation of competence seems to be important to define the quality of teaching.

This study aims to contribute to the understanding of the construct of university teaching competence via a free-association task. In line with previous research [11,14], we used a "bottom-up" approach based on qualitative data obtained by students to explore their meanings. Such a bottom-up approach can be effective because it makes clearer what students really mean by the competent lecturer and could offer lens through which to study the meanings of competence, starting from the students' very own words.

\subsection{European Higher Education Area and the Issue of Evaluation}

The search for the characteristics of a competent university lecturer is not recent. The teaching attributions have been modified in the educational perspective of the European Higher Education Area (EHEA, 2015. Yerevan Ministerial Communiqué. Available online: http: / / ehea.info/page-ministerial-conference-yerevan-2015 (accessed on 15 February 2022); EHEA. 2018. Paris Ministerial Communiqué. Available online: http:/ / www.ehea.info/ page-ministerial-conference-paris-2018; accessed on 15 February 2022), which entails important changes in the educational process that affect the profile of university teaching staff. One of the most important transformations in higher education is the centrality of the educational process with the shift from in-put centred learning processes to out-put centred processes. Thus, the lecturer stops being merely a conveyor of knowledge.

This role reconfiguration demands the development of new talents and the deployment of teaching skills from the university lecturers, as well as the further development of teaching methods, teacher support and professional training, as quality teaching is essential for a quality learning experience for all students.

Students' perception and the evaluation of teaching quality plays a major role in Higher Education. According to the teaching mission of Higher Education as reported in many European documents, the enhancement of teaching should be rooted in the students' needs, which are best assessed through teacher and course evaluation. The involvement and representation of students in governance, viewing students as equal partners, as a part of the academic community and co-producers of knowledge, is considered essential for giving students ownership and responsibility for their learning. Student feedback must be used actively in the development of curricula, learning outcomes and assessment procedures, closing the feedback cycle and paving the way for action to be taken. Teaching evaluations are widespread, and the role played by students is important, as their teaching evaluations (called SETs) seem to be an almost universally accepted method of gathering information about the quality of education [15]. Specifically, documentation produced within the Bologna Process by the National Unions of Students in Europe (ESIB, now ESU) stresses the importance of involving students in the evaluation process in order to promote awareness of being part of university life [16].

In Italy, the quality assurance system in higher education has been introduced by the law 240/2010, which mandated the Government to regulate the quality assurance system in compliance with the main European directives. In 2013 the National Agency for University and Research System Evaluation (ANVUR) has issued guidelines for quality assurance, including the compulsory introduction of a survey of students' teaching evaluations, as well as a common framework for the questionnaire. Prior to 2013, a number of Italian universities independently carried out surveys on students' evaluations of teaching activities. Since the introduction of the national quality assurance system, Italian universities have been obliged to allow students to submit an evaluation questionnaire for all teaching activities (e.g., courses, lab lessons and other activities carried out in the classroom). The results 
of the surveys have been used differently by the universities. Some have been chosen to make public all the results for each teaching activity or each lecturer while others present their results aggregated by degree alone. Moreover, there are cases in which the results are used in incentive schemes or may be used to evaluate promotion and tenure. Furthermore, in Italy, the new certification (ASN), established in Italy in 2010 and launched in 2012, was introduced to filter eligible candidates in the competition for associate and full professorships. Its purpose was to exclude weak candidates on the basis of individual scientific production and the quality of that scientific output (e.g., $\mathrm{H}$ index and articles in top-ranked journals). Teaching activities and academic service play no part in determining the award of eligibility since only indicators of scientific output should be considered by evaluating committees. Teacher expertise-what they know and can do affects all the core tasks of teaching. Without a sustained compensation system that rewards teaching skills, the goal of improving the quality of teaching will remain unfulfilled, and the teaching mission of Higher Education-hile central to the creation of a coherent European Higher Education Area-runs the risk of being overlooked in the development of the Bologna Process.

The ongoing debate on quality assurance includes, amongst others, how to assess teaching quality, the reliability of the student surveys, and the balance between research and teaching quality for the academic career progression. While there are shared professional standards for scientific performance, there is nothing analogous for teaching quality. Since promotion and tenure are built on the impact and the achievements of scientific activity, there is the risk of there being no motivation to improve teaching quality

\subsection{Students' Perceptions of Lecturer Competence}

A number of researchers have explored the general characteristics and competencies that a lecturer should possess in order to be classed as a competent lecturer [17]. Reviewing articles published from the 2000s to 2015 on the attributes of competence in higher education, Yáñez and colleagues [17] identified three main characteristics that constitute an "excellent" teaching: generic competences; pedagogical competences; and disciplinary competences. Firstly, generic competences describe a set of personal, attitudinal and communicative characteristics that are required in any professional area, and the lecturer's proper behaviour. As for the attitudinal characteristics, an excellent lecturer was seen as comprehensive and flexible, acting as a role model, showing passion and interest in their work, organization, motivation and positive attitudes towards students. Personal characteristics referred to a lecturer's sense of humour and honesty. Communicative characteristics described a lecturer's capacity to transfer clear information, openness, assertiveness, and responsiveness $[13,18]$. Secondly, pedagogical competencies referred to a set of abilities, skills and aptitudes that are developed and deployed in the pedagogical context and involve the methods used to facilitate learning (e.g., facilitating critical thinking, encouraging discussion, being innovate in methodology, explaining learning results) [6,19]. Finally, disciplinary competences denoted a lecturer's knowledge, skills and attitudes, which are considered to be as the minimum necessary within each disciplinary field (e.g., to be expert in their disciplinary area; to be up-to-date and concerned with continuous training) [19]. However, there is a scarcity of studies that consider the viewpoint of the key stakeholder of higher education — the student. In the review of Yáñez and colleagues [17], 13 studies focused on students' meanings and evaluations about the attributes of teaching excellence or lecturer competence. Specifically, these studies explored the meaning of "effective teaching" [6-8,20], "best teaching practices" [21], "good teaching" [10-12], "the ideal lecturer" [18,22], and "quality teaching" [13] from the students' perspective. Only one of these articles focused on the meanings of the term "competences" as represented by undergraduate students [19]. In this study, by means of a quantitative cross-sectional method, a series of competencies (e.g., collaborative learning, competencies related to the design of learning tasks, and use of educational technology) were evaluated by students enrolled in a Statistic course at a public university in Chile. Results showed that the competencies most valued by students were general pedagogical knowledge, such as the skill to design 
classroom-appropriate educational spaces and knowledge of the educational implications of ICT.

Even if not specifically referring to the construct of competence, some studies have addressed what quality teaching means for students and what the attributes of teaching excellence are for them $[12,18,23]$. In many of these studies one of the most relevant characteristics of a competent (or good) lecturer was located in the interaction with the students. For instance, by exploring the characteristics of a good university lecturer according to the perception of the students in an Education faculty in Chile, Navarro and colleagues [24] found that the interpersonal aspect of the teacher-student relationship was the most frequently cited category. In Finland, Parpala and colleagues [12] explored university students' conceptions of good/quality teaching by combining qualitative and quantitative methods. The need for good interaction between teachers and students was the most cited category. Clarity of information and the teacher's efforts were also identified as important factors of good teaching. The students also emphasised that good teaching meant fair treatment by the lecturer and a climate conductive to an open exchange of opinions. In 2011, the most relevant characteristics of an ideal lecturer were explored in a sample of Spanish social science university students responding to an open-ended question [18]. Results showed that students' preferred features corresponded to teaching capacity (e.g., explaining tasks clearly, being well organized), good relationship (e.g., using respectful manners, being open), and social capacity (e.g., not being authoritarian). As in the previous studies, great emphasis was placed on characteristics relating to interaction with the students.

In Australia, Glenn and colleagues [20] collected both faculty members' and students' perceptions of optimal learning conditions and effective teaching and learning practices in higher education. Results showed that most students responded that their learning was enhanced when lecturers provided constructive feedback to aid learning. Furthermore, students described the characteristics of an effective lecturer as being one who was passionate, committed, respectful and approachable, well organised and with a broad knowledge of the discipline. In the United States, administrating a two question, open-ended survey asking what qualities university dentistry students liked most and least in a clinical lecturer, Jahangiri and colleagues [8] identified 17 defined categories organized into three core themes: Character, Competence and Communication. Character comprised nine of the 17 defined categories (e.g., being empathetic, patient and fair) and, particularly, the category "caring" (e.g., being encouraging, sincere and helpful) was found to be the most cited by students. Communication comprised three categories indicating the lecturer's capacity to offer constructive comments that encourage and enhance knowledge or students' skills, to listen actively, to appear friendly and receptive to positive interactions. Finally, competence included five of the 17 categories (i.e., being knowledgeable, having expertise, being efficient, skilful and effective). Therefore, in this study, lecturer's competence was defined as the expression of being proficient and abreast with procedures, confident and experienced, able to solve problems, focused, organised and resourceful, expert in the application and demonstration of knowledge, and capable of transferring skills into student's learning. In Mexico, investigating the university students' mental schemata of the "good professor", Casero Martìnez [11] showed the presence of a richly detailed cognitive construct describing a lecturer who proves clear explanation, is a master of the subject, and interacts with students in a participative and motivating way, demonstrating interest, respect and fairness. CaseroMartinez used a "bottom-up" approach based on qualitative data obtained from naïve student participants in the exploration of their perceptions of lecturers' competence and behaviours.

Considering all the afore-mentioned literature, identifying a universal meaning for lecturer competence shared by university students is not a simple task. The heterogeneity of terminologies, approaches, the use of different methodologies (i.e., quantitative crosssectional methods, qualitative and mixed methods) as well as the diversity of samples used make it difficult to draw general conclusions [3]. However, although the conception 
of competence is highly multifaceted, there is agreement among researchers that good teaching positively impacts high-quality learning [12,24,25].

The evaluation of students' expectations about lecturer competence can be crucial in order to clarify teaching competence, recognise indicators to assess these competences, and to support lecturers in developing their roles [1]. Knowing the students' conceptions about the characteristics of competent lecturers could also improve the quality of university teaching that, in turn, impacts on students' professional and academic achievement [26]. Furthermore, the incorporation into EHEA has led to transformations of university education and teaching paradigms in which the students have become the heart of the entire educational process [27]. An argument present in a large body of literature-consistent with a constructivist approach-is the proposition that active student engagement in the learning process produces higher quality learning than a traditional lecture and testing approaches [28,29]. However, little research has been interested in finding out what students themselves think about lecturers' competences and what competences are important to them.

We aim to contribute to the understanding of the construct of university teaching competence starting from the point of view of Italian psychology students, via a freeassociation task. This is a qualitative methodological approach that avoids restricting the collection of information to pre-existing theoretical categories. Specifically, this is framed as a pilot study, conducted in the university Italian field and in the psychological field. In the Italian psychological field, competence requires psychologists to possess the relevant knowledge, skills, and abilities, and to practice them ethically to provide effective services in the areas of experimentation, research, didactic prevention, diagnosis, habilitationrehabilitation and support in favour of individuals, groups, and the community (Norms regulating the Italian Psychologist's Profession, ACT No. 56, 18/2/1989). However, in our investigation with psychology students, we did not choose a specific conceptualization of competence stemming from the literature, but we opted to let the students speak using their own words. The construct of competence does not have absolute validity, in different times, places and with different target groups [17]. Therefore, asking students about their meanings of lecturer competence may reveal interesting and innovative aspects never considered before, or confirm the presence of the same components of competence hitherto conceptualised by scholars. In this sense, this exploratory pilot study aims to shed some lights on the vast number of definitions and components of lecturer competence in the psychological field by exploring students' meanings of competence.

\section{Methods}

\subsection{Participants}

The sample was made up of 122 Italian undergraduate Psychology students, 5 male and 115 female $(94.3 \%, 2$ missing for gender), with a mean age of 21.54 years $(S D=5.58$; range 19-41).

\subsection{Materials and Procedures}

Participants filled in a written questionnaire including a free-association task. Students were asked to write the first five words or short sentences crossing their minds when prompted by the cue word: "What do you think, feel or imagine when I say: "a competent lecturer"? Write down the first five words (or short sentences) that come into your mind." Giving a cue word and asking the respondents to freely associate what ideas crossed their mind gives relatively unrestricted access to mental representations [30-32]. The questionnaire included socio-demographic questions concerning age and gender. (Roles and terms may have different meanings in different countries and learning theories. We referred to a university lecturer regardless of academic career placement level. In Italian, the correct term to refer to a person who teaches university courses is "professore/professoressa" (i.e., "il professore" for male lecturers, "la professoressa" for female lecturers). 
Questionnaires were administered at the end of a social psychology lecture. Two research assistants asked the students in attendance to voluntarily fill in the questionnaire, explaining the purpose of the study, naming the researchers involved and describing the potential use of the collected data. No fee was offered, nor were any university credits offered by way of compensation. Respondents were ensured their anonymity. The lecturer was not present in the room during data collection. Any students unwilling to participate simply left the room. Filling in the questionnaire took approximately $20 \mathrm{~min}$. The research was compliant with the Code of Ethics of the Italian Psychology Association (Associazione Italiana di Psicologia, 2015).

\subsection{Analyses}

The data corpus was a set of word associations or vocabulary about the cue term "competent lecturer", obtained from the students. Two independent judges coded the whole data corpus. The dictionary was processed to make the free-associations more uniform and to reduce the number of categories to be used in the following analysis. For instance, terms that expressed the same semantic content and differed only in grammatical form (gender, singular/plural) were grouped together. In some cases, the participants used short sentences. These were rewritten using a single word which well represented that sentence (e.g., "Curriculum" for the sentence "Competent lecturer has many study certifications"). Synonyms were avoided and long sentences were broken up into single coding unit (e.g., "Up-to-date" was the term used to unify the following sentences: "be updated", "know what's new"). Controversial or ambiguous cases were discussed with a third judge, experienced in qualitative content analysis.

The data corpus underwent a lexical Correspondence Analysis (CA) [33], using the ASPAR procedure of SPAD-T $[33,34]$. SPAD-T integrates statistical methods to textual domain to describe, synthesize and classify textual information [35]. CA allowed for the graphic representation of answers, grounded in the principle of proximity/distance. After that, a hierarchical cluster analysis showed the existence of four different clusters of participants. Finally, the clusters were projected onto the two factorial plans resulting from the lexical CA, and graphically representing the lecturer competence [36].

\section{Results}

Altogether, participants produced 468 associations, with a mean of 3.84 associations per participant. The number of distinct categories was 89 , that is $19.02 \%$ of the original answers. Twenty-six categories, whose frequency was higher or equal than 4 , were selected to undergo the lexical CA (see Table 1).

Table 1. List of the 26 categories with frequency $\geq 4$.

\begin{tabular}{cccc}
\hline Words/Categories & Frequency & Words/Categories & Frequency \\
\hline Available & 50 & Strict & 9 \\
Skilful & 43 & Serious & 8 \\
Empathetic & 28 & Respectful & 7 \\
Clear & 26 & Professional & 6 \\
Well-read & 25 & Sociable & 6 \\
Captivating & 24 & Fair & 6 \\
Good-Explanation & 19 & Concise & 6 \\
Meticulous & 18 & Kind & 5 \\
Motivated & 16 & Practical & 5 \\
Charismatic & 15 & Participative & 5 \\
Up-to-date & 11 & Open & 4 \\
Interactive & 9 & Nice & 4 \\
\hline
\end{tabular}

Two factors were extracted, explaining $14.05 \%$ total inertia. With lexical CA, it is common that the percentage of total inertia is low as it is based on the number of possible 
factors (i.e., $\mathrm{k}-1, \mathrm{k}$ is equal to the number of categories, in this case $\mathrm{k}=26$ ). In order to select the significant categories, we chose the rule a.c. $\geq 100 / \mathrm{n}$ of categories (a.c. $\geq 3.85$ ). Figure 1 shows the factorial plan originating from the crossing of the first and second factors.

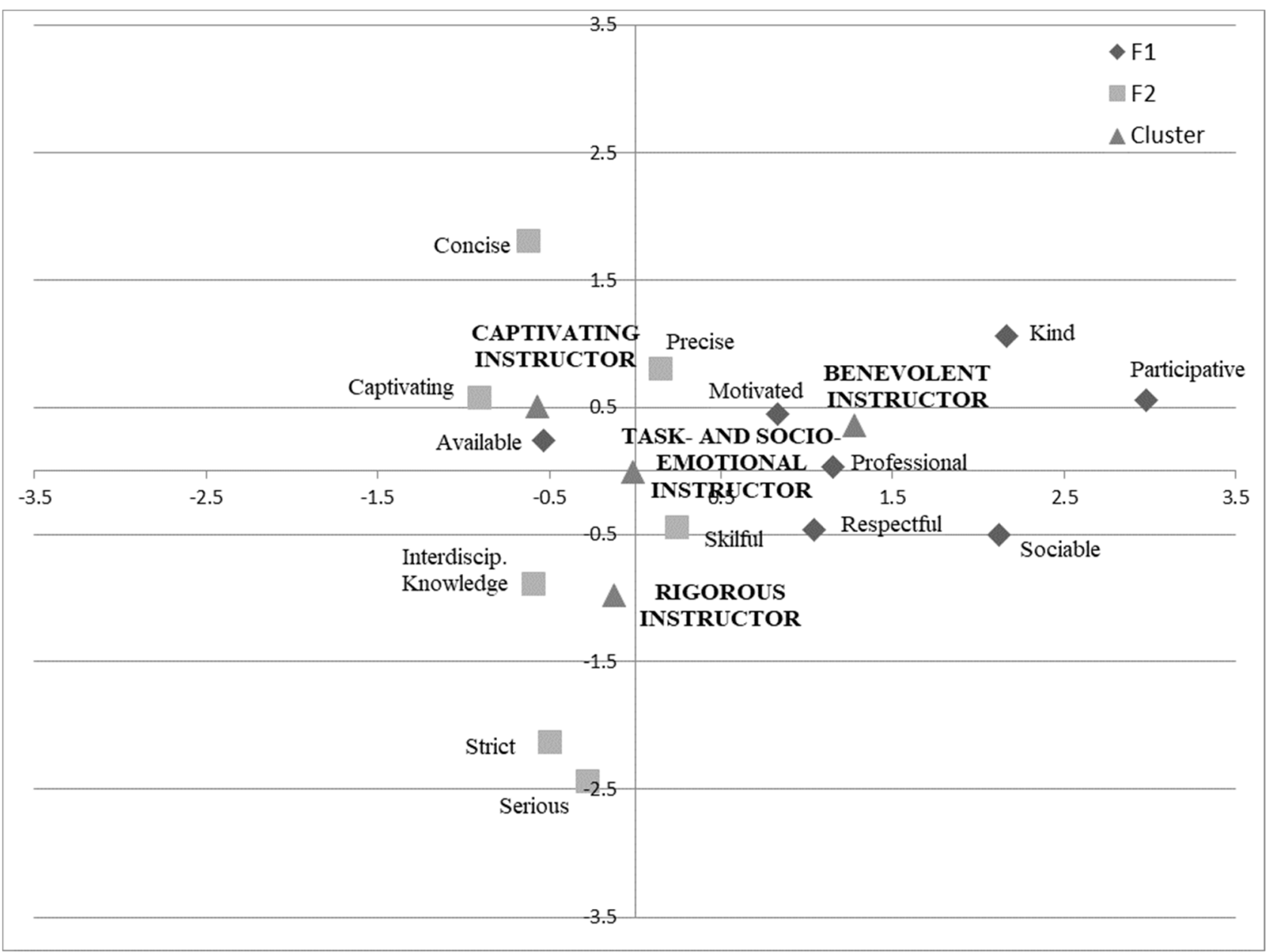

Figure 1. Correspondence and Cluster Analysis. Note. Only words loading on the factors are displayed in this figure.

On the first axis "socio-emotional dimension" (explained variance $=7.20 \%$ ), we found the opposition between, on the left pole, the socio-emotional specialists, described with words such as "captivating" (a.c. = absolute contribution) =10.4) and "available" (a.c. = 7.3); while on the right pole, the benevolent lecturer described as "participative" (a.c. = 23.0), "sociable" (a.c. = 13.9), "kind" (a.c. = 12.0), "motivated" (a.c. = 5.7), "professional" (a.c. = 4.1) and "respectful" (a.c. = 3.9).

As for the second axis "task specialist" (6.85\% of explained inertia), on the negative pole a lecturer emerged who is competent with regard to the content-area and the interdisciplinary literacy. Examples of words were "serious" (a.c. = 25.8), "strict" (a.c. = 22.2), "interdisciplinary knowledge" (a.c. = 3.9) and "skilful" (a.c. = 4.5). On the positive pole, a task-oriented lecturer still emerged, with a communication literacy, described as "concise" (a.c. = 10.6), "meticulous" (a.c. = 6.2) and again "captivating" (a.c. = 4.3).

The two axes recalled the "task specialist" and "socio-emotional specialist" dimensions developed by Bales and Slater [37], concerning leadership role differentiation. It referred to the development of types of leader roles during group interaction: instrumental roles, those that were involved with the achievement of the task goals, and expressive roles, those that were involved with the internal integration of group members. The task specialist was 
responsible for task achievement while a socio-emotional specialist was responsible for group maintenance [38].

Cluster analysis revealed four groups of participants, with four different representations of the lecturer competence (see Table 2). The first cluster $(n=35)$ described the captivating lecturer, as "practical", capable of making a synthesis ("concise"), who were at the same time "nice", "open" and "available". This representation points to a lecturer capable of involving and amusing students.

Table 2. Categories characterizing the four clusters.

\begin{tabular}{|c|c|c|c|c|c|c|c|}
\hline \multicolumn{2}{|c|}{$\begin{array}{c}\text { Cluster 1- } \\
\text { "Captivating" Lecturer }\end{array}$} & \multicolumn{2}{|c|}{$\begin{array}{c}\text { Cluster 2- } \\
\text { Lecturer Oriented to } \\
\text { Both Task and } \\
\text { Socio-Emotional } \\
\text { Aspects }\end{array}$} & \multicolumn{2}{|l|}{$\begin{array}{c}\text { Cluster 3- } \\
\text { Rigorous Lecturer }\end{array}$} & \multicolumn{2}{|c|}{$\begin{array}{c}\text { Cluster } 4- \\
\text { Benevolent Lecturer }\end{array}$} \\
\hline Categories & $V$-Test & Categories & $V$-Test & Categories & $V$-Test & Categories & $V$-Test \\
\hline Captivating & 5.5 & Skilful & 2.6 & Strict & 5.0 & Kind & 3.8 \\
\hline Practical & 2.9 & Empathetic & 2.6 & Serious & 3.8 & Participative & 3.8 \\
\hline Open & 2.5 & Clear & 2.5 & Well-read & 3.1 & Impartial & 3.3 \\
\hline Nice & 2.5 & Interactive & 2.2 & Interdisciplinary Knowledge & 2.1 & Professional & 2.6 \\
\hline Concise & 2.4 & Up-to-date & 2.2 & & & Respectful & 2.3 \\
\hline Available & 2.3 & Fair & 2.0 & & & & \\
\hline
\end{tabular}

The second cluster was the biggest one $(n=43)$ and referred to the image of lecturer who was at the same time both task- and socio-emotionally oriented. Meaningfully, this cluster was located at the crossing of axes. This lecturer was described as competent considering both the didactic subjects ("skilful", "clear", and "up-to-date") and the relational dimension ("empathetic", "interactive", and "fair").

The third cluster $(n=25)$ recalled the task-oriented lecturer. This lecturer was rigorous and described as "serious", "strict", "well-read", with an "interdisciplinary knowledge."

The fourth cluster $(n=19)$ pointed to a lecturer very sensitive to the students' needs and principles related to the role of teacher. This lecturer was defined as "kind", "participative", "impartial", "professional", and "respectful" of all students. Therefore, this lecturer was described as being inclined to participate and to be interested in the students' requests, without adopting favourites (see also Figure 1).

\section{Discussion}

This qualitative pilot study explored the meanings of lecturer competence emerging from a convenience sample of undergraduate Psychology students in Italy, collected from a free-association task. Textual data analysis identified some fundamental dimensions organizing the meaning of lecturer competence: the first axis was called "socio-emotional dimension" and the second one "task specialist". The socio-emotional specialist was described with words such as "captivating", "available", "participative", "sociable", "kind", "motivated", "professional", and "respectful". As for the task dimension, the task specialist was described as "serious", "strict", possessing "interdisciplinary knowledge", "skilful", "concise", "meticulous", and again "captivating". These qualitative results confirm the plethora of terms and meanings attached to the adjective "competence" already identified in previous studies [17]. The terms found in this study recalled elements from the teacher-centered vs. student-centered paradigms in pedagogical literature in which knowledge is not transferred from teacher to students but the latter are actively involved in the learning process [39]. These dimensions also recalled the role differentiation originally described by Bales and Slater in task-oriented groups made up of between three and five members [37,40]. They observed that the group member scoring highest on contributing ideas (called the "instrumental" leader) was not the same person chosen as the best liked (called the "expressive" leader). This role differentiation was seen as a fundamental social process common to all 
groups. This tension inevitably produces a task specialist responsible for task achievement and a socio-emotional specialist responsible for group maintenance [37]. Although these results occurred in ad-hoc discussion groups, the theory of role differentiation has since been applied to aspects of the family [41], to complex organizations [42], to sport psychology [43] and has become a tenet of many theories of group leadership [38]. Research into leadership tended to maintain the two dimensions of group behaviour, that is group maintenance and task achievement (Pfeffer, 1978), and leaders were felt to indulge in one or other of these types of behaviour.

Critics of role differentiation theory $[44,45]$ did not question the validity of differentiating leadership functions into instrumental and expressive components; rather they were not convinced of the incompatibility of these roles for group leaders [44]. After reanalysing the original data presented by Bales and Slater, and reviewing other studies on role differentiation, Lewis [44] concluded that instrumental and expressive roles were not incompatible and often tended to be integrated.

Our results showed that this reasoning was still present in everyday meanings of the competent lecturer, almost 75 years after the original work by [37]. However, our results and the orthogonal representation of the two dimensions on the factorial plan pointed to the independence of the two dimensions. One lecturer could be located in any of the four quarters of the factorial plan, being the lecturer high in both expressive and instrumental roles, or low in expressive and high in instrumental roles, or low in both expressive and instrumental roles, or high in expressive and low in instrumental roles. Research reviews support the idea that shared leadership, in terms of coexisting formal and informal leaders, increases motivation and shared mental models facilitating the coordination of actions within groups $[46,47]$. Furthermore, in line with recent research, teaching projects that combine multiple representations or idea of competence are found to be the most effective curricula, particularly in the fields related to people's health [27].

From a methodological point of view, a novelty of this study relies in the use of computer-assisted program such as SPAD-T to analyse textual data on lecturer competence via lexical-metric analysis. This software is commonly used in the study of the content and field of social representations of certain social objects [48].

Students' meanings of lecturer competence are important both from the point of view of the educational perspective of EHEA, and from the need to improve teaching quality. In general, with reference to the educational perspective of EHEA, the results of the study seem to reflect and be in line with the changes in the educational process that affect the profile of university teaching staff after the Bologna Process, and in particular with the reconfiguration of the role of the university lecturer: from being merely a transmitter of knowledge to one who teaches how to learn. The importance assigned by the participants to the relational dimension is indicative of how the issue of the educational process-one of the key categories of the educational perspective of EHEA-is now a heritage as well as a criterion for judging the quality of university teaching, also for students.

Out cluster analysis revealed the presence of four representations of the competent lecturer. The biggest cluster of participants described the competent lecturer as being oriented to both task and socio-emotional aspects at the same time. Students show cased their need for a lecturer to be competent in their subject and, at the same time, pay attention to their relational needs as well as to deliver fair treatment. This is consistent with previous findings $[8,12,18]$ showing that the relevant characteristics of an ideal lecturer correspond with teaching skills as well as good social aptitude.

The second most frequent cluster referred to the captivating lecturer, as a representation of a lecturer capable of engaging and amusing students thanks to interpersonal and communication skills. In this case, the students emphasised that competent teaching meant a lecturer's social abilities, charisma, good communication skills, in line with the results of other studies $[18,23]$. Furthermore, in this cluster there were some references to a lecturer's digital competences. This aspect also emerged in recent research as a fundamental element 
to meet the demands of the highly skilled professions of the future, and therefore, prepare students for it $[49,50]$.

The third cluster referred to a rigorously task-oriented lecturer. In this case, the lecturer was described as well-read and serious. This description is in line with other studies in which participants described lecturer competence as the set of knowledge, expertise, skills, with a predisposition to be up-to-date and concerned with continuous training $[8,19]$. Active student participation in the learning process is not mentioned here. In the same vein, in the traditional teacher-centered pedagogy, teacher assumes pivotal responsibility for the communication of knowledge to students and this implies that lecturers are in the best position to decide the structure and content of any given classroom experience [28].

The smallest cluster pointed to the benevolent lecturer. This lecturer was defined as being caring, impartial, respectful to students and interested in creating a participatory climate between students and lecturers. In educational contexts, the lecturer's benevolence was already described as being one of the most important aspects of trustworthiness that decrease students' sense of vulnerability and are vital to their learning [51-54].

\section{Study Limitations}

This pilot study had some important limitations that ought to be kept in mind when interpreting the results. First of all, we are aware of the exploratory nature of the study. The sample is of limited size and is mainly made up of female Psychology students, leading to low representativeness of the sample. Future research should explore the same topic in a more representative and balanced sample of students. The role of the lecturer's and the participants' gender was not investigated. Following some studies within the Stereotype Content Model (SCM) [55], future studies could explore the representations of the lecturer's competence in the case of male and female faculty members. Furthermore, the representation of a lecturer teaching different subjects, such as STEM, should be investigated as differences might emerge as compared with the representation of a lecturer teaching psychology. Nevertheless, this pilot study may offer some indications concerning the most important components of competencies for psychology students. These qualitative findings could offer elements for more systematic quantitative research in the future. For example, it could offer suggestions for the construction and validation of comprehensive instrument measuring lecturer competence. Future studies could start from the participants words to formulate new items measuring endorsement of different conceptions of lecturer competence, items organized according to the two extracted factors. After being validated, the instrument could be used in future quantitative studies to compare the representation of the lecturer competence between different fields of study (e.g., social sciences, life sciences etc.) and different countries (e.g., Western and non-Western countries).

\section{Conclusions}

A complex representation of the competent lecturer emerged in the words of a group of Italian undergraduate psychology students, covering several areas of the competence already emphasized in other research investigating the meaning of the competent lecturer or of good teaching. This study highlights the importance for faculty development to focus on those areas related to both the relational and instrumental aspects of competences, in order to fulfil students' expectations and provide an effective teaching environment. Furthermore, this study results recalls teacher-centred vs. student-centred paradigms in pedagogical literature. In accordance with the constructivist paradigm in education, which places a student at the heart of educational process, and fundamental principles of the Bologna Process, our results suggest the value of different approaches to teaching (e.g., captivating, task and socio-emotional oriented, rigorous and benevolent); the need to enhance motivation for learning, to develop good social relations, interdisciplinary knowledge and the skills required for fieldwork. 


\begin{abstract}
Author Contributions: Conceptualization, C.B., S.D.B. and M.P.; formal analysis, G.M., S.D.B. and M.P.; investigation, C.B., S.D.B. and M.P.; methodology, C.B., S.D.B. and M.P.; project administration, C.B. and S.D.B.; supervision, C.B.; visualization, C.B. and S.D.B.; writing-original draft, S.D.B., C.B., G.M. and M.P.; writing-review and editing, S.D.B., C.B., G.M. and M.P. All authors have read and agreed to the published version of the manuscript.
\end{abstract}

Funding: This research received no external funding.

Institutional Review Board Statement: The study was conducted according to the guidelines of the Declaration of Helsinki and the Code of Ethics of the Italian Psychology Association (Associazione Italiana di Psicologia, 2015).

Informed Consent Statement: Informed consent was obtained from all subjects involved in thestudy.

Data Availability Statement: Not applicable.

Acknowledgments: We would like to thank Felice Carugati for his useful suggestions on the Sections 1 and 3.

Conflicts of Interest: The authors declare no conflict of interest.

\title{
References
}

1. Mulder, M.; Gulikers, J.; Biemans, H.; Wesselink, R. The new competence concept in higher education: Error or enrichment? J. Eur. Ind. Train. 2009, 33, 755-770. [CrossRef]

2. Trinchero, R. Costruire, Valutare, Certificare Competenze. Proposte Di Attività per La Scuola; Franco Angeli: Milan, Italy, 2016.

3. Westera, W. Competences in education: A confusion of tongues. J. Curric. Stud. 2001, 33, 75-88. [CrossRef]

4. García-Valcárcel, A. Características del "buen professor" universitario segúne studiantes y profesores universitario [The "good professor" characteristics according to students and teachers]. Rev. Investig. Educ. 1992, 10, 31-50. Available online: https: / / dialnet.unirioja.es/servlet/articulo?codigo=764529 (accessed on 15 February 2022).

5. Pascual, I.Y.; Gaviria, J.L. El problema de la Fiabilida den la Evaluación de la eficiencia docenteen la universidad: Una alternative metodológica [The problem of reliability in the evaluation of teaching efficiency at the university: A methodological alternative]. Rev. Española Pedagog. 2004, 229, 359-376. Available online: https:/ / revistadepedagogia.org (accessed on 15 February 2022).

6. Alweshahi, Y.; Harley, D.; Cook, D.A. Students' perception of the characteristics of effective bedside teachers. Med. Teach. 2007, 29, 204-209. [CrossRef] [PubMed]

7. Bartram, B.; Bailey, C. Different students, same difference? A comparison of UK and international students' understandings of 'effective teaching'. Act. Learn. High. Educ. 2009, 10, 172-184. [CrossRef]

8. Jahangiri, L.; McAndrew, M.; Muzaffar, A.; Mucciolo, T.W. Characteristics of effective clinical teachers identified by dental students: A qualitative study. Eur. J. Dent. Educ. 2013, 17, 10-18. [CrossRef]

9. Bhattacharya, B. What is 'good teaching' in engineering education in India? A case study. Innov. Educ. Teach. Int. 2004, 41, 329-341. [CrossRef]

10. Cabalín, D.; Navarro, N. Conceptualización de los estudiant essobreel buen profesor universitario en las carreras de la salud de la Universidad de La Frontera-Chile. Int. J. Morphol. 2010, 26, 887-892. [CrossRef]

11. Casero Martinez, A. ¿Cómo es el buen profesor universitario segúne la lumnado? Rev. Española Pedagog. 2010, 68, 223-242. Available online: https:/ /https:/ / www.jstor.org/stable/23766298 (accessed on 15 February 2022).

12. Parpala, A.; Lindblom-Ylänne, S.; Rytkönen, H. Students' conceptions of good teaching in three different disciplines. Assess. Eval. High. Educ. 2011, 36, 549-563. [CrossRef]

13. Martínez, M.; del Mar, M.; García, B.; Quintanal, J. El perfil del professor universitario de calidad desde la perspectiva del alumnado [The profile of a quality university professor from the student's perspective]. Educación 2006, 9, 183-198. [CrossRef]

14. Di Battista, S.; Pivetti, M.; Berti, C. Competence and benevolence as dimensions of trust: Lecturers' trustworthiness in the words of Italian students. Behav. Sci. 2020, 10, 143. [CrossRef] [PubMed]

15. Zabaleta, F. The use and misuse of student evaluations of teaching. Teach. High. Educ. 2007, 12, 55-76. [CrossRef]

16. O'Driscoll, C.; Fröhlich, M.; Gehrke, E.; Isoski, T. Bologna with Student Eyes. 2015. Time to Meet the Expectations from 1999. European Students' Union. Available online: https:/ / files.eric.ed.gov/fulltext/ED578176.pdf (accessed on 15 February 2022).

17. Yáñez, O.J.; Orsini Sánchez, C.; Hasbún Held, B. Atributos de una docencia de calidad en la educación superior: Una revision sistemática [Attributes of quality teaching in higher education: A systematic review]. Estud. Pedagógicos 2016, 3, 483-506. [CrossRef]

18. Marín, M.; Martinez, R.; Troyanor, Y.; Teruel, P. Student perspectives on the university professor role. Soc. Behav. Personal. Int. J. 2011, 39, 491-496. [CrossRef]

19. Friz, M.; Sanhueza, S.; FigueroaManzi, E. Concepciones de los estudiantes para professor de matemáticas sobre las competencias professional es implicada sen la ensenanza de la estadística [Pre-Service Mathematics Teachers' Concepts Regarding the Professional Competencies Involved in the Teaching of Statistics]. Rev. Electron. Investig. Educ. 2011, 13, 113-131. Available online: http:/ / www.scielo.org.mx/scielo.php?script=sci_arttext\&pid=S1607-40412011000200008 (accessed on 15 February 2022). 
20. Glenn, D.; Patel, F.; Kutieleh, S.; Robbins, J.; Smigiel, H.; Wilson, A. Perceptions of optimal conditions for teaching and learning: A case study from Flinders University. High. Educ. Res. Dev. 2012, 31, 201-215. [CrossRef]

21. Basow, S.A.; Phelan, J.E.; Capotosto, L. Gender patterns in college students' choices of their best and worst professors. Psychol. Women Q. 2006, 30, 25-35. [CrossRef]

22. Davies, B.; Leung, A.; Dunne, S. So how do you see our teaching? Some observations received from past and present students at the Maurice Wohl Dental Centre. Eur. J. Dent. Educ. 2012, 16, 138-143. [CrossRef]

23. Navarro Merellano, E.; Almonacid-Fierro, A.; Moreno-Doña, A.; Castro-Jaque, C. Buenos Docentes universitarios: Quédicen Los, Estudiantes? [Good University Teachers: What Do Students Say about Them?]. Available online: https://repositorio.uautonoma. $\mathrm{cl} /$ handle/20.500.12728/5317 (accessed on 15 February 2022).

24. Ramsden, P. Learning to Teach in Higher Education, 2nd ed.; Routledge Falmer: London, UK, 2003.

25. Vermunt, J. The power of teaching-learning environments to influence student learning. In Student Learning and University Teaching; Entwistle, N.J., Tomlinson, P.D., Eds.; British Psychological Society: London, UK, 2007; pp. 73-90.

26. Barrie, S.C.; Ginns, P.; Prosser, M. Early impact and outcomes of institutionally aligned, student focused learning perspective on teaching quality assurance. Assess. Eval. High. Educ. 2005, 30, 641-656. [CrossRef]

27. Gradellini, C.; Gómez-Cantarino, S.; Dominguez-Isabel, P.; Molina-Gallego, B.; Mecugni, D.; Ugarte-Gurrutxaga, M.I. Cultural Competence and Cultural Sensitivity Education in University Nursing Courses. A Scoping Review. Front. Psychol. 2021, 12, 682920. [CrossRef]

28. Mascolo, M.F. Beyond student-centered and teacher-centered pedagogy: Teaching and learning as guided participation. Pedagog. Hum. Sci. 2009, 1, 3-27.

29. Sharan, S.; Shaulov, A. Cooperative learning, motivation to learn, and academic achievement. In Cooperative Learning: Theory and Research; Sharan, S., Ed.; Praeger: New York, NY, USA, 1990; pp. 173-202.

30. De Rosa, A. Le réseau d'associations. In Méthodesd'étude Des Représentations Sociales; Abric, J.-C., Ed.; Érès: Ramonville Saint-Agne, France, 2003; pp. 81-117.

31. Deschamps, J.C. Analyse des correspondances et variations des contenus de représentations sociales. In Méthodes d'étudedes représentations sociales; Abric, J.-C., Ed.; Érès: Ramonville Saint-Agne, France, 2003; pp. 179-199.

32. Pivetti, M.; Melotti, G.; Bonomo, M. An exploration of social representations of the Roma woman in Italy and Brazil: Psychosocial anchoring to emotional reactions. Int. J. Intercult. Relat. 2017, 58, 12-22. [CrossRef]

33. Lebart, L.; Salem, A.; Berry, L. Exploring Textual Data; Springer Science \& Business Media: New York, NY, USA, $1997 ;$ Volume 4.

34. Doise, W.; Clemence, A.; Lorenzi-Cioldi, F. Représentations Sociales Et Analyses de Données [Social Representations and Data Analysis]; PUG (Presses Universitaires de Grenoble): Grenoble, France, 1992.

35. Bertaut, M.B.; de Soto, L.R.G. Textual data analysis computer system SPAD-T. Application example to post-war Spanish press. In Applied Stochastic Models and Data Analysis, Proceedings of the Fifth International Symposium on ASMDA 1991, Granada, Spain, 23-26 April 1991; World Scientific Publishing Company: Singapore, 1991; p. 75.

36. Bonomo, M.; Melotti, G.; Pivetti, M. Social Representations of the gypsy woman among non-gypsy Brazilian and Italian population: Psychological and social anchoring. Psicol. Teor. E Pesqui. 2017, 33, 1-10. [CrossRef]

37. Bales, R.F.; Slater, P.E. Role differentiation in small decision-making groups. In Family Socialization and Interaction Process; Parsons, T., Robert Freed, B., Eds.; Free Press: Glencoe, IL, USA, 1995; pp. 259-306.

38. RogerRees, C.; Segal, M.W. Role differentiation in groups: The relationship between instrumental and expressive leadership. Small Group Behav. 1984, 15, 109-123. [CrossRef]

39. Barber, M. Reassessing pedagogy in a fast forward age. Int. J. Learn. 2007, 13, 143-149. [CrossRef]

40. Slater, P.R. Role differentiation in small groups. Amer. Soc. Rev. 1955, 20, 300-310. [CrossRef]

41. Zelditch, M., Jr. Role differentiation in the nuclear family. In Family: Socialization and Interaction Process; Free Press: Glencoe, IL, USA, 1955; pp. 307-351.

42. Etzioni, A. Dual leadership in complex organizations. Am. Sociol. Rev. 1965, 688-698. [CrossRef]

43. Loughead, T.M.; Hardy, J.; Eys, M.A. The nature of athlete leadership. J. Sport Behav. 2006, 29, 142-158.

44. Lewis, G.H. Role differentiation. Am. Sociol. Rev. 1972, 37, 424-434. [CrossRef]

45. Meeker, B.F.; Weitzel-O'Neill, P.A. Sex roles and interpersonal behavior in task-oriented groups. Am. Sociol. Rev. 1977, 42, 91-105. [CrossRef] [PubMed]

46. Burke, C.S.; Fiore, S.M.; Salas, E. The Role of Shared Cognition in Enabling Shared Leadership and Team Adaptability. In Shared Leadership: Reframing the Hows and Whys of Leadership; Pearce, C.L., Conger, J.A., Eds.; Sage Publications: Thousand Oaks, CA, USA, 2003.

47. Solansky, S. Leadership Style and Team Processes in Self-Managed Teams. J. Leadersh. Organ. Stud. 2008, 14, 332-334. [CrossRef]

48. Brondi, S.; Pivetti, M.; Di Battista, S.; Sarrica, M. What do we expect from robots? Social representations, attitudes and evaluations of robots in daily life. Technol. Soc. 2021, 66, 101663. [CrossRef]

49. Guillén-Gámez, F.D.; Mayorga-Fernández, M.; Bravo-Agapito, J.; Escribano-Ortiz, D. Analysis of teachers' pedagogical digital competence: Identification of factors predicting their acquisition. Technol. Knowl. Learn. 2021, 26, 481-498. [CrossRef]

50. Guillén-Gámez, F.D.; Mayorga-Fernández, M.J. Prediction of factors that affect the knowledge and use higher education professors from Spain make of ICT resources to teach, evaluate and research: A study with research methods in educational technology. Educ. Sci. 2020, 10, 276. [CrossRef] 
51. Romero, L.S. Trust, behavior, and high school outcomes. J. Educ. Adm. 2015, 53, 215-236. Available online: https://eric.ed.gov/ ?id=EJ1055550 (accessed on 15 February 2022). [CrossRef]

52. Tschannen-Moran, M. Trust Matters: Leadership for Successful Schools; Jossey-Bass: San Francisco, CA, USA, 2004.

53. Tschannen-Moran, M. Fostering teacher professionalism in schools: The role of leadership orientation and trust. Educ. Adm. $Q$. 2009, 45, 217-247. [CrossRef]

54. Tschannen-Moran, M.; Hoy, W.K. A multidisciplinary analysis of the nature, meaning, and measurement of trust. Rev. Educ. Res. 2000, 70, 547-593. [CrossRef]

55. Fiske, S.T.; Cuddy, A.J.C.; Glick, P.; Xu, J. A model of (often mixed) stereotype content: Competence and warmth respectively follow from perceived status and competition. J. Personal. Soc. Psychol. 2002, 82, 878-902. [CrossRef] 